\title{
Security and Stability of the Gulf Region in Light of Iranian Threats
}

\author{
Hani Mefleh O. Hamdon ${ }^{1} \quad$ Barjas Habbas Alkumeet $^{2} \quad$ Sayel F. Alserhan $^{1}$ \\ 1.Al al-Bayt University - jordan $\backslash$ almafraq \\ 2.The Higher Council for Science \& Technology (Jordan)- jordan $\backslash$ almafraq
}

\begin{abstract}
The study aimed to examine the strategies of the Arab Gulf states to address the Iranian threat, and also seeks to identify the extent to which the United States adheres to international law in its policy towards the treatment of weapons of mass destruction in the Gulf region, and also seeks to clarify the risks and potential Iranian threats now and in the future of the Arab Gulf states, which will instill concern and fear among the Arab Gulf states in what will result under the Iranian agreement and the countries $(5+1)$, and a regional neighbor with ambitions in the region in general, and use in the historical and analytical approach, and the use of the methodology, historical and analytical, The study concluded that the continuation of the State of Iran and its unlimited pursuit of nuclear technology, prompts the countries of the region to follow in the footsteps of the Iranians, permeably under the pretext of peaceful civilian purpose, and at the same time we find that an unstable region such as the Arab region and the fear of the danger expected from Iran may be the motive and the real reason behind the pursuit of nuclear technology by others in the region.
\end{abstract}

Keywords: The Arabian Gulf region, Iranian threats.

DOI: $10.7176 / \mathrm{IAGS} / 85-03$

Publication date:August $31^{\text {st }} 2020$

\section{Introduction}

The Arab Gulf region has been affected by the dramatic (large and rapid) changes that have taken place internally and in the Middle East around it, as well as the international system since the early 1990s. The issue of external and internal security for most of the Gulf states has played an important role in the public policies of these countries, and internal relations between the Gulf states have evolved in different directions ranging from cooperation to war, and international and regional factors have also overlapped in the crystallization of the issue of security, its concepts, components and trends, and has affected several serious shifts in the gulf states' perceptions of security, especially as it is under international pressure in the international system aimed at maintaining the interest of oil flow and reasonable prices for consuming countries.

The Gulf region enjoys great importance in the international political balance, and this importance stems from the importance of geographical location, which is a link between the continents of the ancient world, Asia, Europe and Africa, and that it is the meeting point of disparate trade, which has made it a field of long-term conflict for the purpose of acquiring it and controlling its trade routes and natural treasures, and this conflict continues to rage to this day (Elephant, 1988).

The term Arabian Gulf geographically is called the water flat between Iran to the east and the Arabian Peninsula to the west, and between Iraq in the north, the Gulf of Oman and the Strait of Hormuz to the south, the largest sea in the Indian Ocean, and it is connected through the Arabian Sea through the Strait of Hormuz, which forms its bottleneck. It is bordered by seven Arab countries: Iraq, Kuwait, Saudi Arabia, the United Arab Emirates, Bahrain, Oman and Qatar, while Iran has its eastern coast (Hiti, 1981).

The discovery of oil has compounded the geostrategic importance of the Gulf region and even makes it the focus of global policies, and many researchers have even agreed that the future of the free world, and the industrialized countries, is linked to the rich oil fields in the Middle East, a statement reinforced by the growing oil discovery that confirmed that the Gulf Gulf countries have the largest oil reserves. In the world, statistics show that Saudi Arabia alone has nearly a quarter of the world's reserves, with a total of nearly 263 billion barrels, Kuwait and the United Arab Emirates ( 9 percent), Qatar more than 1 percent, Bahrain and Oman, Iraq nearly 11 percent and Iran by more than $(8$ percent $)$, reaching the equivalent of 64 percent. The importance of Gulf oil is compounded by the fact that there are large areas in the area that have not been excavated (Bistaki, 2003).

In addition to the economic importance of oil, the Arabian Gulf region contains huge amounts of natural gas reserves estimated at about 2,509 trillion cubic feet, which is equivalent to 40 percent of the world's reserves, with Iran ranked second in the world by about 974. Qatar ranks third with 910, Saudi Arabia fourth with about 240 and the UAE by 124 trillion cubic feet in the fifth place in proven natural gas reserves (Yasin, 2008, p. 53).

There is no doubt that our current era is the oil age, oil for a century has been the maker of prosperity in peacetime and guarantor of victory in time of war, and no one can argue that oil has enabled the United States of America to reach the peak of power on the world, while the oil of the Gulf states, the oil that the world needs is 
increasingly needed, especially the United States of America (Idris, 2000).

Study problem:

Iraq's exit from the equation of the balance of military power in the region has created chaos that poses a real challenge for the GCC countries, as the major Gulf state, and their continued absence as a regional balance has opened the door for Iran to dominate the Gulf region to impose control over its countries. Iran is at the forefront of the Middle East alongside Israel after the end of the Cold War in the production, development and competition of nuclear, chemical and biological weapons of mass destruction, and this has led to an escalation of panic, tension and crises in the Gulf region, prompting the Gulf states to enter an arms race with Iran, successive Iranian threats to the Gulf states, the nuclear race and military exercises. that you're doing in the Arabian Gulf,

Study questions:

The study will try to answer the following main question:

What are the strategies of the Arab Gulf states to address the Iranian threat?

In addition to the following sub-questions:

1. What is the impact of regional and international changes on the strategies of the Arab Gulf states to address the Iranian threat?

2. What are the preparations and strategies that the Arab Gulf states are pursuing in addressing the Iranian threat?

The importance of study:

The importance of the study lies in clarifying the strategies of the Arab Gulf states to address the Iranian threat, and its importance can be explained by two aspects:

1. Scientific importance: This study comes in the light of the scarcity of studies that dealt with the topic of strategies of the Arab Gulf states to address the Iranian threat, thus forming a useful reference for researchers and those wishing to know the nature of duplication in those standards.

2. Practical importance: The practical importance of this study comes in its attempt to highlight all the developments resulting in the double standards exercised by the United States towards weapons of mass destruction, although there are some general principles and agreements on the use of weapons of mass destruction in international and humanitarian law.

\section{5 study objectives:}

This study aims to research the strategies of the Arab Gulf states to address the Iranian threat, and also seeks to achieve a range of objectives, including:

1- To identify the extent to which the United States adheres to international law in its policy towards the treatment of weapons of mass destruction in the Arab Gulf region..

2- To clarify iran's current and future potential risks and threats to the Arab Gulf states, which would instill concern and fear among the Arab Gulf states, as the situation under the Iran agreement and the 5+1 countries will result in, and the presence of a regional neighbor with ambitions in the region in general.

Research methodology:

The study of international relations requires a set of scientific research methods that benefit from full information on all the vocabulary of the relationship that governs countries among themselves, and determines the guidance of these countries and the implications of these policies, and this study is based on the following approaches:

\section{Historical approach:}

The study adopted this approach in order to track the various events that the Arab Gulf region has experienced, as the historical approach is based on the fact that contemporary international relations have roots and extensions, history remains an auxiliary element of political analysis, it provides us with proven or contrary evidence of our imposition, as it is useful in comparative studies of the one phenomenon, and what has occurredto it development or to compare it with other phenomena, through a historical and temporal sequence of events in order of occurrence, while deepening the description of certain events, and the detection of the causes that led to them.

Analytical Approach: This approach focuses on the importance of proper understanding of international developments, by identifying the purpose and objectives of the state, sequencing its interests and analyzing repeated phenomena in the policies of other nations.

The study adopted this approach, in order to analyze the strategies of the Arab Gulf states to address the Iranian threat Iraq and Iran case study, and through this approach will analyze the mechanisms used by countries in order to achieve their interests and their ability to achieve personal and common gains.

Theories adopted by the study:

This study is based on the theory of realism in international relations, and is based on the hypothesis that states always seek to strengthen their power, and the most prominent of those who spoke about it is Hans Morkintha, who stressed that the essence of international politics is based on two fundamental pillars: power and interest, and that interest is determined within the framework of force, and that states seek power and are obliged to do so 
to avoid destruction, and in their origins the school of realism is based on the theory of the state of nature at Hobbes, starting from the saying that human beings are determined by the power, and that states seek to seek power and are obliged to do so to avoid destruction, and in their origins the real school is based on the theory of the state of nature at Hobbes, starting from the saying that man is based on the saying that human beings are seeking to seek power and are obliged to do so to avoid destruction. This natural state in Hobbes's mind is linked to the absence of organized power, since as long as human beings live without the cover of a common authority they respect, they are in a state of war, and the only way to avoid permanent recourse to violence is to establish an authority that human beings can protect to live in peace (Tawfiq, 2000).

\section{The theoretical philosophy of the real school:}

The real school emphasized the need to understand and interpret international policies as they are, not as they should be, that they study the real variables and forces that are active in international politics, and thus considered history and its evidence as a key material to confirm the validity of its diagnosis and to establish the conviction that there is a essence of international politics reached by one means, namely, power, (Khazraji, 2005).

If we come to the data and foundations of the theories of power and the main concepts on which it is based, we will find them as follows:

1- The state takes the center of its analyses, and sees it as the core of international behavior and the cornerstone of the entire international system.

2- The theories of force do not believe that there is a consensus in the fundamental national interests of the states parties in the international system, and it is these reformist contradictions that produce international conflicts and lead to war when the methods of peaceful settlement fail to resolve their roots and causes, and the force plays a very influential role in determining the course of those conflicts and determining the outcome of the end.

3. The power of realistic theory analyses is not just military force or material hate in a narrow sense, but a national force in its comprehensive sense with its various elements and material and non-material components, including but not limited to population, natural resources, strategic location, level of technological development, ideology and diplomacy, propaganda, public opinion and the level of armaments.

4- The realists link the impulse to reach power and move it in the direction of influencing others to the ultimate goals set by states for itself, and the human nature controlled by latent instinctive conflicts that cannot be eliminated or separated from them, namely, identifying conflicts of power and the desire to subdue others and bullying them as a kind of self-affirmation behaviour and ensuring the ability to survive and continue to face all forms of external threat and challenge.

5- It considers moral principles as worthless only if they are exploited in propaganda, or if they agree with the power of the state and do not represent a burden on them, or an obstacle to their consolidation and development (Copycat, 1982).

Through political realism, Morkenthau interprets international politics as a struggle for power, and describes international relations by arranging interests and activities hidden behind the concept of force, but international politics as part of all determined by the central importance of the interest, so he emphasizes that it is a struggle for power among nation states, every nation is preoccupied with conflict and every nationality must settle or organize its actions towards the requirements of force, and based on the position related to the power and distribution of the international order, options The key countries within the system are determined by: Maintaining the status quo, i.e. maintaining the existing distribution of forces at a certain historical moment.

(b) Expansion or imperialism, i.e. seeking to reverse the status quo in order to achieve and promote additional guarantees and interests, and by using military, economic or cultural force.

\section{2 Previous studies:}

Study (Bayoumi, 2009) entitled:Arabs between Iranian influence and the American-Zionist scheme. The study addressed the changes and developments of the U.S. attitude towards Iran under the neo-conservatives, and talked about the Russian and Chinese role in the region and the change of the balance of international power, and also addressed the regional role shared between Iran, America and Israel in the region, and the position of Arabs between Iranian orientations and American ambitions in the region through the introduction of Saudi-Iranian relations and the Role of the Gulf and Arab, and discussed the iranian nuclear file and the possibility of directing a military strike to Iran from the United States, and also addressed the idea of supporting citizenship in the Gulf Arab countries and containing minorities, especially with regard to Shiites in those countries.

The study (Samadi and Bani Melhem, 2009) entitled:"Iran's Nuclear Program andthe Security of the Arabian Gulf: (AnalyticalStudy)" which aimed to show the effects of the Iranian nuclear program and its implications on the nature of security in the Gulf ) Statement on the effects of Iran's nuclear program region, starting from the assumption that: "The benefits that Iran's nuclear program can bring to Iran and the security, economic, social, political and military implications of the countries of the region and their societies in the event 
of a new and devastating war as a result of this program requires everyone - the countries of the region and those interested in them - to look to solve the problem with a kind of Everyone's got to be interested. seriousness, care and speed before it worsens." The study reached several conclusions and proposals, the most important of which is that the security situation in the Arab Gulf region is intheneed to build a security strategy in line with regional and international conditions and the security requirements of the countries of the region.

This study concluded that The impact of Iranian armaments on Gulf security since the Islamic Revolution 1979 since the 1979 Islamic revolution, Iran has sought to develop its conventional military capabilities, whether land, sea, air, and nuclear technology, and to make many arms deals with a number of countries to become an influential regional power that qualifies it to control the region, and to take an important role in the Gulf regional system, which in the past has played a global role as a global player in the past. As indicated by the study of Iran's desire to control the agenda of the work of Islamic countries, in order to achieve its objectives, which has a very important impact on the Arab Gulf states, especially in light of the changing balance of power in the region after the 2003 Iraq war on the one hand and iran's quest to develop its nuclear capabilities on the other.

The study (James, 2008) entitled "Regional threats and security strategy:the current worrying situation in the Middle East and this study issued by the Center for Strategic Studies of the College ofAmerican War, the study talked about instability in the Middle East and its impact on global security, She also talked about the Iraq war in changing the balance of power in the region, coinciding with the presence of a group of internal and external factors that in turn put pressure on the ruling elites in the Middle East, namely the existence of alliances between major powers and non-international actors such as the alliance between Iran, Syria, Hezbollah, Hamas and some Shiite militias and political organizations in Iraq, they considered themselves as successful resistance forces against the United States of America and Israel in Palestine, Lebanon and Iraq, and thus the increased popularity of these forces in the region is a fundamental challenge to the ruling elites of the ruling In order to increase the risk of Iranian Shiite tides for The Sunni countries in the Gulf and the region in general, which led these countries to establish balanced political relations among themselves to fill the vacuum created by the deterioration of American influence in the region, in return for Iran's progress towards the acquisition of nuclear weapons, which contributed to the increase of its regional power, which is strengthened after the invasion of Iraq, where Iran exerts influence in Iraq.

A study carried out (Nafia, 2005) entitled "The situation of the region after ayear of the invasion and occupation of Iraq"the author pointed out that there are a number of facts that are well remembered regarding the invasion and occupation ofIraq: The first fact: the decision to launch the war on Iraq was a purely American decision taken by the American administration against the will of the international community, without consultation with anyone, and for reasons related to its global strategy only, and that it was only a link in an extended crisis that has not yet ended its chapters and is still open to all possibilities, Fact 2: The gap between the stated U.S. goals and their hidden objectives still exists and grows wider every day, and attempts to achieve any of them face great difficulties on the ground to the point where the chances of success of the U.S. strategy are even with the possibility of its failure. The third fact is that the countries of the world have reacted to the American decision from the perspective of the extent to which it affects their interests, and that few of them have been able to adapt to it and find some political, moral or legal justifications for it. (Nafe'a, 2005)

A study carried out (Carison, 2003) entitled: Action or Isolation: Americans Ponder U.S. Role" in this study the researcher surveyed the opinions of Americans towards their desire for the United States of America to play an active role in trying to solve global problems, especially the war against Iraq and get rid of the ruling regime, and concluded that a large percentage of the sample of the study do not support the policy of President Bush

A study carried out by(Dunne, 2003) entitled: "TheUnited States, The United Nation and Iraq", explains the chronology of Iraq's history and relations with both the United States and Britain, and finds that the United States of America after the events of September 11, 2001, and after its success in the war on Afghanistan wanted to get rid of the Iraqi regime in order to achieve its interests in Iraq in addition to supporting the interests of the Zionist entity.

\section{The impact of regional and international changes in double standards towards weapons of mass destruction}

Security of the Arab Gulf region in light of the proliferation of weapons of mass destruction

The proliferation of weapons of mass destruction and the means to carry them to their most far-reaching targets have been an important aspect of the debate on security in the Gulf region since at least the 1970s. After that, the Gulf War in 1991 put these concerns at the forefront, especially among Western observers, and then strongly reinforced the atmosphere that followed the events of September 11 and the subsequent talk of the "axis of evil", and then the war waged on Iraq in 2003, as a matter related to the national security strategy and the situation in the region. In fact, the perceived interdependence between weapons of mass destruction and terrorism and the possibilities of action and access between different parts of the world makes developments in the Arab Gulf a matter of American domestic affairs as well as regional security. What makes weapons of mass destruction so 
prominent in contemporary Arab Gulf calculations? For decades, strategies have accepted the risk that the nuclear battle will be the "permanent factor", and regional security discussions have recognized the potential for escalation and the potential for future use of nuclear or chemical weapons. Nuclear weapons and long-range missiles have been part of the regional equation since the Suez crisis in 1956, at the very least, when Russia threatened (though not entirely true in that threat) of nuclear strikes against Britain and France in response to their intervention in Egypt. In 1967, and again in 1973, the spectrum of nuclear confrontation between the great powers in the context of the Arab-Israeli conflict was on the horizon(Bradley,2004).

Israel's nuclear deterrent has been a factor in regional security for decades, and Israel has not hesitated to maintain its monopoly on nuclear power in the region from the destruction of Iraq's nuclear reactor in 1981. Then came the end of the Cold War to break that recognized link between regional conflicts and expectations of escalation and then the drift of the superpowers and the possibility of the use of weapons of mass destruction. The post-Cold War era provided all players, both regional and external, with greater freedom of action, reducing the risk associated with intervention, but at the same time removing many of the old restrictions on conduct within the region(Gad,2009).

In a world where outside players can tell themselves about the consequences of Middle East differences, military technology providers, including equipment and techniques related to weapons of mass destruction, are less cautious about the circulation of such materials. The Soviet Union was a major sponsor and equipped with conventional heavy military equipment during the Cold War, but it was nevertheless reluctant to send the technology that was expected to lead to escalation so as not to complicate its security plans. But the economic and political incentives of the Russians, or other external players, to send weapons of mass destruction-related equipment to the Gulf region may now outweigh the expected caveats. Today, many other factors contribute to highlighting the importance of weapons of mass destruction and long-range missiles in Middle East security (Blauna,2004).

First, the Arabian Gulf is the region where non-conventional weapons and long-range missiles have been used in recent conflicts, although that use has been in a limited adaptive manner. Iraq used it against the Kurds and was widely used in the Iraq-Iran war. The missiles were used in the 1973 Arab-Israeli war (such as Egyptian Scud missiles and Syrian Frog-7 missiles), used in the "urban war" between Iran and Iraq, in the civil war in Yemen, and during the Gulf War in 1991 (Bayoumi,2009).

Secondly, the Arabian Gulf is an advanced area of proliferation, even if they have not already been used. Most of the world's major exporters of weapons of mass destruction are on an arch route from North Africa to Pakistan (nuclear weapons and missile tests in South Asia could also affect proliferation standards in the Persian Gulf region). The presence of active conflicts and hot spots throughout the region means that the possession of weapons of mass destruction is not only a matter of national prestige and strategic weight, but a fully real factor that has its presence in military budgets and in any war fought (Hanna, 2009).

Thirdly, the importance of weapons of mass destruction in the security environment of the Gulf region is surrounded by serious doubts about the motives of regional players and their strategic culture. The methods of thinking about weapons of mass destruction, particularly nuclear weapons and missiles, which had developed during the Cold War period, are often thought to be far from the situation and backgrounds of the Gulf region. It remains unclear whether the "outlaws" arms publishers will act rationally or whether they can be deterred if necessary by conventional logic. On this and other issues, the prospect of conflicts in the Arab Gulf, which may include the use of weapons of mass destruction, may include all kinds of issues that are not satisfactory to Western strategists, and even the regional players themselves, presumably. The ongoing Palestinian-Israeli confrontation, bearing the risk of regional escalation, is gaining greater weight and immediate weight (Haidar,2011).

Fourthly, the characteristics of the proliferation of weapons of mass destruction in the Arabian Gulf are of great interest to players from outside the region. Russia, China, North Korea, and others are the main suppliers of weapons, materials and technical knowledge required to develop local capabilities. While pursuing peace and seeking a way to supply energy in the region are issues of exceptional importance among all other world affairs, america and the West will be forced to continue to pay attention to them. For these and other reasons, the region requires a Western presence and military intervention. The proliferation of weapons could interfere with a peace process and with stability in the Gulf and the Mediterranean region (Rifaat,2006).

The emergence of new and potential nuclear powers in the region in the future, and the accompanying deployment of missiles with longer range, could change western intervention and engagement calculations in the Persian Gulf in a deep and complex way. These calculations may also change the transition to a "world of defences", both operationally and strategically. As the war on Iraq in 2003 showed, the issue of possessing weapons of mass destruction and the prospect of future use of weapons of mass destruction could serve as a justification for war itself. Finally, America's growing concern about weapons of mass destruction capabilities in the Persian Gulf reflects a deeper concern about us security within its own territory, especially after the September 11, 2007 attacks. 
The emergence of the phenomenon of global terrorism and its apparent links to the Arabian Gulf, when taken with the growing level of lethality caused by "new terrorism,"are also the warnings of terrorists' use of weapons of mass destruction within The United States." The ease with which people, materials and technologies can move means that the proliferation of weapons in the Arabian Gulf will not be a phenomenon that takes place far away from the United States and its allies. Whether these weapons are transported by long-range missiles or by agents, high-destructive weapons are the most dramatic and visible examples of the new security environment's characteristics of the ability to move across areas (Scott,2009).

The vast expanse of the weapons, which they can reach, is challenging traditional notions of regional security. Fassia, the Arabian Gulf, Europe, Eurasia and the entire Western hemisphere are more reliable on each other than ever before. The proliferation of weapons of mass destruction in the Arabian Gulf has an impact on security throughout the globe, and developments elsewhere far away could affect the patterns of proliferation of weapons of mass destruction within the region. Taken together, it is clear how important weapons of mass destruction are in the security of the Gulf region. It demonstrates the growing link between the issue and developments outside and within the region. The chapter reviews several assessments of the excellent sources available for weapons of mass destruction programmes and proliferation trends. It focuses on analysing proliferation developments and what they mean for the region's security and strategy, and then assesses current trends and their impact on the proliferation controversy.

\section{Strategies of the Arab Gulf States to Address iran's threat}

Iran's security vision for the Gulf region is that there should be joint security arrangements in the region, based on the historical, religious and economic relations between its countries while ensuring the independence of the Gulf states, and the rejection of foreign interference in their arrangements under any form, and that allowing the continued presence of western power in the region is conditional on the lowest number of troops and weapons, and therefore the Iranian project for gulf security is based on:

1- The Gulf states must agree to reach a unified understanding of common interests.

2- Keeping foreign countries away from the region, especially the major countries.

3- Working to keep the Gulf countries away from their Arab depth. (Khalid bin Sultan al-Saud, 1997)

Iran's Threat to Gulf National Security

The fact that the Gulf national security is linked to the Arab national security system as a whole is an irrefutable fact, and we also find it clear that the dangers, however diverse they may be, would also harm the Arab national security directly. Addressing the sources of threats is one of the most important priorities to determine where the threat comes from, and how to deal with it in order to preserve the gulf national interest and our maintenance of the Arab national security system in general.

The following will be addressed the most important of these dangers and threats, which are related to Iran, Iran is already an Islamic republic and a regional neighbor of the Arab Gulf states, and since the issue of strengthening relations is necessary because it is a country that has weight in all the Arab region and not only the Gulf, not only the various interests, but the follower of Iran's political approach and its trends that are not even and disturbing over time, actually finds that there is cause for astonishment and concern, since Iran, although iran has no rights to usurp or any other. It is not clear that Iran is maintaining suspicious and unclear relations with non-Arab political regimes, all of which warn that dealing with Iran must be cautious, in order not to guarantee its aggressive intentions, specifically its expansionist ambitions and dream of leading the Muslim world through its Shiite approach.

To address the threats and the Gulf-Iran conflict in recent years, we mention the following:

1. The Iranian-Gulf conflict has reached the door of the Security Council, where Tehran has called on the UN Security Council to intervene in the Bahraini crisis and protect Shiites, which called for an urgent meeting of foreign ministers of the Gulf Cooperation Council (GCC) in Riyadh, and issued a strongly worded statement calling on the international community and the Security Council to intervene to stop what has been described as "blatant Iranian interference" in the affairs of the GCC states (Amal Raslan, 2011).

2. It is true that the conspiracy theory has become a heavy-handed word, and even notorious for many elites and the general Arab population, but this does not prevent foreign hands that are as messing with as much as possible to turn the legitimate Shiite community's demands in the Gulf and Bahrain into a tool for liquidation or bargaining to achieve or gain new gains on the regional and international arenas (Al-Mallah, 2011).

3. Iran continued to escalate its media war against the Arab Gulf states, both officially and religiously, and denounced what it called "Gulf intervention in the Yemeni conflict", according to Parliament Speaker Ali Larijani, who called for negotiations with the Houthis (Naba News, 2009).

"The export of the revolution has an independent administration known in the Iranian Foreign Ministry, and it works systematically to impose Iranian hegemony, not only on the Gulf states or Arab countries, but also on African countries that have geostrategic advantages, as in the case of the State of Eritrea, where they entered that 
poor country to exploit its position, at the entrance to the South Red Sea, which controls the Suez Canal, through which they can threaten Yemen and Saudi Arabia and pass their weapons on Sudan and then to Egypt. They also set up a military base in Eritrea and an oil refinery. "We must convince the Arab countries of the danger of Iranian ambitions, and we must move security in monitoring Iran and its arms aimed at interfering in the region and the need to cut off these arms first Powell," he said.

In addition to providing stability in Lebanon and Gaza, all of this limits iran's role, as well as the need for the Egyptian-Saudi coalition to face this role. (Zayed and Issa, 2011).

"Iran, in the light of its expansionist dreams, kuwaiti academic Dr. Ayed Al-Manaa said and its technical attempts represent a danger even to itself, not only the Gulf states, since in the light of this frantic Iranian race to build nuclear reactors that could cause a nuclear and human disaster in the Gulf region, al-Manaa explained that Iran interfered in the Saudi affair by attempting to assassinate the Saudi ambassador in Washington, and intervened in Kuwait through spy networks that have been He also called on the Gulf states and Arab countries to unite their positions to counter the Iranian threat, especially since the attempts of Shi'ism have reached many Arab countries, and this could be an entry point for interfering in the affairs of these countries in the future.(alarabia Net, 2011).

In addition, if we look at Iran's ambitions over the past time, we can conclude that:

A-. History shows iran's interest since it was a pre-Islamic Persian state in the western Gulf region and the Arab region.

b- The Former American-Iranian Alliance led to the emergence of ambitions in the region, which led to the claim of Bahrain in 1970, and the occupation of the islands of Greater Tunb, Lesser Tunb, and Abu Musa of the United Arab Emirates in 1971, which is still under Iranian occupation, and rejects any peaceful solutions on it.

c-. Iran's ambitions continued even after the fall of the Shah, as it declared that it retained the territorial gains made by the Shah's regime, both on its border with Iraq and its occupation of the Uae islands.

D- It adopted the principle of exporting the revolution, and continues to adopt it despite the announcement that it abandoned it after the Iran-Iraq war.

E- It seeks to be part of any security arrangements in the Arab Gulf, does not accept any foreign interference, even if it is Arab, and always tries to isolate the countries of the region from their Arab world (Ruwaili, 2010).

$\mathrm{f}$ - The latest was published in the Bahraini newspaper Al-Ayyam, which indicates that the Supreme Leader of the Republic, Ali Khamenei, has been in charge of the affairs of the Gulf Arab states. "The united states will not be able to do so," he said. "Our capabilities are beyond their capabilities, and they have to be more careful," "(Kuwait Qabas, 2005)

Saudi Arabia has worked to link its national security to the security of the Gulf Region, and as a result, the forms of Iranian threat to gulf security can be seen as the same as those of Iran's national security, which are a match between ideological, political, economic, military and nuclear threats.

\section{Ideological threat}

This threat emerged with the success of the Iranian revolution, and specifically since 1980, and represented the policy of exporting the revolution, which aimed to create a global Islamic revolutionary movement, hostile to western powers, especially America, iran has initially won the establishment of an islamic solidarity, dispelling the idea of Sunni-Shiite differentiation, and besides fighting foreign enemies, Iran aimed to fight the enemies of the inside and they are corrupt Muslim governments", which prevent the victory of Islam (Tokville, 2008).

In his words, Khomeini called for the "export of the revolution" to replace the political regimes in the Arab Gulf with other regimes that would be allies of Iran (Badib, 1983).

Before the revolution, religious relations were characterized by the two countries, but after the revolution, Iran began to aspire to play a leading role in the Islamic world in general, and the leadership of the Shiiteworld in particular, iran tried to attract Shiites and impose its political dominance on the regions where they constitute the majority, and this led to Iran's tendency to compete with Saudi Arabia in the Islamic leadership (Ma, 1996).

Iran has targeted the Saudi regime by launching media attacks aimed at questioning the legitimacy of saudi arabia's monarchy and relying on the idea that the monarchy is contrary to Islam, which fights tyranny (Idris, 2000).

Here are two forms of ideology that pose a major threat to Saudi national security internally and externally:

On the domestic front: Saudi Arabia's Shiites are linked to Iranian scholars through the literature and statements of the Shiites of the two countries, and Khomeini's experience is the best evidence of this correlation between the Shiite fabric inside and outside Iran. There is no doubt that the victory of the revolution in Iran, led by religious scholars, gave a moral boost to the Shiites of the kingdom, and within these limits it was acceptable and natural, because the political ripples lead to domestic repercussions not only on a specific group of the population but on all neighboring countries and peoples, and its impact on the size of the existing internal imbalance" (Al-Haitham, 2009). 
This link between Saudi Shiites and Iranian Shiites religiously and politically created a direct internal threat to Saudi national security, which is particularly active during the hajj season, where After the revolution, Iran worked through its pilgrims to politicize the hajj seasons to spread their ideas among Muslims, and to organize demonstrations denouncing Western powers and Israel, without regard to Saudi laws, and these Iranian policies led to the severing of diplomatic relations with Saudi Arabia in 1988 due to political demonstrations, in which 400 Iranian pilgrims were killed (Abdnasser, 1991).

The historical context indicates that the Shiite issue within Saudi Arabia has focused entirely on the Shiites of the eastern region, particularly since this region contains the largest oil reserves in the world, estimated at 25 percent of the world's total reserves, so the demands of the Shiite groups for this region have focused on improving economic and social conditions, and many studies indicate that the Shiites of the eastern region have close contact and association with areas of heavy Shiite presence in neighboring areas of Iraq, Iran, Bahrain and Kuwait (Hassan, 2009).

On the external level: The Iranian ideological threat to Saudi national security is linked to the Shiite minorities scattered in the Arabian Gulf, and this link was one of the main reasons for the strained relations of Iran and the rest of the Arab Gulf, including Saudi Arabia. This connection, as well as the factors of religious-political association in Shiite thought, contributed to the development of what could be considered a geopolitical reality that could not be overlooked in the light of the transformations that accompanied the US invasion of Iraq (Al-Mas'ad, 2000).

The transformations that took place in the region after the American invasion of Iraq led to the social and political rise of the Shiite groups in the Gulf region, and the emergence of The Shiites of Iraq not only as a dominant force within Iraq, but also as a Shiite Arab force, represents a pre-warning to all Gulf Arab states, especially since this threat is based on a fundamental problem, namely, that The Shiites of Iran realize that the limits of their power and influence end with the borders. Iran's geography, while the Shiite minorities in the rest of the Gulf states have the ability to cross their geographical borders as a rising power, which poses the risk of double identity by the rise of these Shiite minorities in the Arabian Gulf, and their division between the identity of their countries to which they belong, and their religious identity, which belongs to the supreme Shiite religious authority in Iran (mohammad 2007).

Since the revolution, Iran has supported these minorities, and there are three examples of this role that directly threaten sexist national security of Saudi Arabia:

\section{First: Bahrain's Shiites and The Iranian Role:}

Bahrain is located within the territorial sea of Saudi Arabia, i.e. Bahrain is a strategic depth of Saudi national security, and there is no doubt that the Gulf Cooperation Council has arranged international rights and obligations for Saudi Arabia over Bahrain, and has arranged international rights and obligations for Bahrain over Saudi Arabia, as long as Bahrain is a strategic depth of Saudi national security, Saudi Arabia from within and outside the Gulf Cooperation Council is responsible for Bahrain's security under international agreements approved by international law. Among them are the Al Jazeera Shield forces, which had already entered Kuwait and participated with the coalition forces in the removal of Saddam Hussein's forces from Kuwait in 1990, during which time the Iranian government was the first supporters and welcome supporters of the entry of the Island Shield forces into Kuwait, and today these same forces are advancing to Bahrain to eliminate the riots and establish stability, and security in all the young kingdom and for the benefit of its people first and foremost (Sa'ate, 2011).

The demographic reality in The Shiite-majority Bahrain, which has contributed to the crystallization of political and social unrest between Sunnis and Shiites, is a fertile ground for Iranian intervention and support for the majority in order to eliminate bahrain'sSunni regime. According to historical information, sectarian tensions in Bahrain between Sunnis and Shiites peaked in 1981, when a radical Shiite movement based in Iran, the Islamic Front for the Liberation of Bahrain, staged a coup against the regime in Bahrain with the aim of establishing a regime whose tires belong edifying the Shiite majority, after the liquidation of the ruling family and members of the cabinet (Hassan, 2009).

When Saudi Arabia signed a border agreement with Bahrain in 1985, Iran opposed it and threatened to withdraw from any international organization including Bahrain, Ayatollah Sadiq Rouhani announced Iran's refusal to recognize Bahrain (Al-Mas'ad, 2002).

The Sunni-Shiite attraction in Bahrain has worsened after the Arab Spring, creating a permanent crisis affecting Bahrain's national security, which is considered a threat to Saudi national security, which was represented by tens of thousands of Bahraini people in a mass march, which has not been seen in the Gulf region since at least the middle of the last century, which made the government of Bahrain and the governments of the cooperation countries The Gulf is in a very critical position to impose its repercussions on moving in more than one political, economic and military track in order to stop the march of these demonstrations within certain limits and prevent them from moving to other Gulf states, which prompted the King of Bahrain to declare a state of emergency, and to instruct the commander of the defense forces to take all necessary measures to protect the 
safety of the country and citizens.

The Gulf and saudi arabia's concern over the strongness of these demonstrations, which are seen as representing Shiites and drawing some support from the Shiite Republic of Iran, and the fear that these protests will be passed on to the rest of the Gulf Cooperation Council( GCC) countries, in an indication that the GCC countries are pushing to respond decisively to these protests before the crisis worsens politically, economically and socially in the Gulf region, which is strategically important and oil-importing to international powers, particularly the United States of America.

As part of the joint defense policy and the Al Jazeera Shield forces tasked with protecting the GCC countries from foreign interference, Tehran has announced that it will not stand idly by towards Saudi and Gulf intervention in Bahrain. To achieve its demands for ending the monarchy and transforming Bahrain into a Shiite Islamic republic in the style of the Shiite Republic of Iran (Qatishat, 2011).

\section{Second: The pro-Iranian Houthi movement:}

In view of the crimes and assassinations committed by The Lebanese Hezbollah and its branches, and the rejection of the Yemeni Muslim people for such a party and its beliefs and agenda aimed at penetrating the Twelver Shiite society, this name was removed and replaced by another name, namely (al-Shabaab believers) in the 1990s A number of Zaidis were recruited who turned into (Twelver Shiites) or remained on their Zaidi doctrine, but were lured to be a tool and arm of Iran's twelve-dozen influence in Yemen, and at the head of this pyramid (Hussein Badr al-Din al-Huthi), They were originally from the Garudia band to the twelve-year-old Jaafari a day early, and he confirmed this by going to Iran and from its Safavid source (Sadiq, 2006).

There are many indications that Iran is supporting the Houthi movement in Yemen, including:

I. The strong relations between the Iranian revolution and the Houthi supplications, which increased after the cordial residence of Badr al-Din al-Huthi in Tehran in Qom, after a succession with Zaidi scholars around the Imamate palace in the Hashemite patriarchs "Hassan and Hussein" without others, which was believed to be true in exchange for the diligence of others, saw that time has passed this issue, in order to avoid embarrassment with the rulers of Sana'a republicans, and returned to Yemen only after the establishment of yemeni unity, after the mediation of a number of scholars of the Yemeni uniform.

- What was raised about visits by (Houthis) to Iran for the purpose of organizing and training, not to mention secret visits by Iranian military experts, included secret meetings with groups associated with the Union of Faithful Youth, not to mention the clear Iranian media support, especially by the media affiliated with the movement of the Revolutionary Guide.

ج- Hundreds of Iranian religious scholars gathered in front of the Yemeni embassy in Tehran during the third round between the government and the Houthis in late 2005 to protest what they called massacres against Shiites in Yemen, demanding the expulsion of the Yemeni ambassador from Tehran, and changing the name of the street where the Yemeni embassy is located to the name of al-Houthi (Taher, 2009 p. 160, 161).

The most important impacts on Saudi national security can be summed up through the turmoil in the Yemeni arena and the Saudi clash with the Houthis in northern Yemen as follows:

A- The Saudi intervention in northern Yemen and the continuation of the confrontation with the Houthis for all this period and the saudis suffered all these human and material losses may represent a factor of exposure to the security of Saudi Arabia, thus encouraging some groups to undertake some adventures, especially in light of the imbalance of American power and the situation of attrition to which the American force is exposed. Continued clashes between Saudi Arabia and the Houthis are the worst option in the current regional and international situation, while peaceful disengagement is the least costly option.

(b) The instability prevailing in Yemen and the weakness of the central government affect the Gulf states in general and Saudi Arabia in particular, specifically, the instability or the slide of Yemen into Somalia could have a profound impact on the Gulf, particularly Saudi Arabia.

A- Yemen could become a security shelter for al-Qaeda elements to train, plan and prepare for major operations against Western interests inside the Gulf, particularly Saudi Arabia.

D- There is also the risk that Yemen, due to its geographical location, will become a safe passage way for drug trafficking and illegal immigrants from africa and Asia (Faqih, 2011).

Third: Iran's support for the Shiite minority in Saudi Arabia:

With the outbreak of the Shiite Islamic revolution in Iran, there were widespread unrest in the eastern region in 1979, in response to Khomeini's call for Saudi Shiites to revolt against the ruling regime, and the Saudi Guard was able to control the situation during this period, but tension soured between Shiites and the state until the end of the Iran-Iraq war, and the 1990s saw a rapprochement between Saudi Arabia and Iran, which had a positive impact on the Relationship of Shiite Shiites with the Saudi state, but after the American invasion of Iraq, 40 intellectuals drafted a document entitled "Partners" At home, they called for rejecting all forms of discrimination and exclusion that they believe are being practiced against them, and calling on the government to apply the principle of equal opportunities in higher administrative and political functions and allowing them to practice 
their religious rites without restriction or prohibition. This reflects the Saudi government's focus on improving the economic and living conditions of the people of this region (Abu Amud, 2007).

Many political analysts have expressed their perception that the clashes that took place in the Shiite town of Al-Awamiyah in 2011, which lies in the east of the kingdom, carry a clear Iranian significance and message to the Gulf states, stressing that Tehran will not stand as a observer only of what is happening in the region, especially after the failure it achieved in Bahrain and the high probability of the fall of its strategic ally Syria.

"What happened is a message from Iran to the Gulf states that it will not be silent on the loss of a strategic ally, Syria..

"Iran's expansionist objectives in the region are well known and its interventions are visible," said Dr. Sadaka Fadhil, a professor of political science at King Abdul Aziz University in Jeddah.

\section{Political threat (pursuit of regional hegemony):}

Judith Yath, a U.S. researcher at the Institute for National Security Studies who specializes in regional affairs, believes that there are three basic concepts that shape Iran's view of its role in the world:

"1. Iran as a unified society of identity and strength.

Islam.

3. Fares as a source of historical and national pride."

It is the first time that Iran has been accused of being a terrorist group.

First, the need to emphasize Iran's dominant regional role in the Gulf and beyond the Gulf:

Iran's religious leaders believe that Iran's natural right and historical destiny is to dominate the region and also to lead the Muslim world, and in addition, they believe Iran has a direct interest in all regional issues.

Second: The need to strengthen Iran's capabilities to defend itself in the face of any military aggression:

Iran's leaders here are seeking independence and strategic and tactical self-reliance, especially in the military, hence the concern for nuclear technology and possibly the ability to possess nuclear weapons."

"Iran assumes that this dominant role is a natural right in the Gulf and throughout the Middle East, considering that it is the largest country in terms of population, the largest military power and the oldest civilization," he said. As the most advanced country in the world, and the region that Iran aspires to extend its hegemony beyond the Gulf, it extends from Afghanistan to the Gulf to the entire Middle East, and because it considers itself a dominant regional power, it expects to be consulted on all issues in the region without exception, it believes that the way America's exit from Iraq must pass, as well as the settlement of the ArabIsraeli conflict, as well as stability in the Gulf. All of this must pass in their opinion through Tehran" (Zahra, 2007).

This behavior aimed at regional hegemony over the Arab region and the Arabian Gulf in particular threatened Saudi national security directly, and was linked to this threat by an automatic reaction that created a state of competition between Iran and Saudi Arabia for the leadership of the regional regime in the Gulf, and Iran's behavior towards the Gulf region was based on four factors:

1- The Gulf is of vital importance to Iran's national presence as an independent presence, and it is highly sensitive to any real or potential challenge because Of iran's interests in the region.

2- The geographical blocs surrounding Iran and its vast area, and its military and economic power (Soviet Union, Indian continent, Turkey) pose a major challenge for them in exercising their regional influence, while the Arab Gulf states are the weakest link among their neighbors.

3. The Arabian Gulf is its only maritime port due to the difficult mountainous terrain overlooking the Gulf of Oman.

4- Iran's oil wealth is found in the Khuzestan region and the Persian shelf of the Gulf, without which Iran becomes one of the poorest countries in the world, making it very closely linked to the Arabian Gulf.

These factors and influences, the most important of which is that the Gulf states are the weakest link in the face of Iran's regional expansion, has made Iran, and warned it of the importance of hegemony in this region, and as mentioned, the pursuit of Iran's regional hegemony exists before the Khomeini revolution in 1979, and iran's pursuit of this hegemony affects the collective security of the Arabian Gulf, and saudi national security in particular (Abdullah, 2005).

\section{Geo-economic threat:}

Iran's strategic position is the bayonet of economic threat in the face of Saudi Arabia and the Gulf states, where it is a link between East and West as a natural corridor for world trade between the Near East and the Mediterranean Basin, it has been called the key of east and west, which gave it the opportunity to communicate with different countries because it is the vital route in the import and export process between both East and West (Saadoun, 1995)

Accordingly, Iran's geographical location and its oil and gas production plays a prominent role on the international scene, as it is linked to the most important strategic areas in the world, namely the Middle East, the Arabian Gulf, Central Asia, and therefore Iran can be considered a regional player and influential by virtue of its strategic position through: 
1- Located in the sensitive area of the Indian Ocean in the path of the most important lines of communication between East and West.

2- It is the intersection of transportation routes from the Sea of Oman and the Red Sea to north and east Africa and Europe.

3- It is located on the top of the roads of the Middle East, Central Asia and the Caucasus near the southern border of Russia.

4- The role it plays through communication between the countries of modern Central Asia.

5- Its ability to access open waters, its connection to the Indian subcontinent through the Sea of Oman and Pakistan and its role in securing the future energy needs of The Countries of China and India through this route (Dajman, 2007).

It also acquires Iran's control over the three Emirates islands it occupied in 1971. Iran enjoys a large number of ports in the Gulf and the Sea of Oman. Iran controls More than 40-30\% of the world's oil tankers are crossed by more than 40-30 tankers per day, with an average of 6 minutes per tanker at peak hours. From the western and northern coasts of the Muzandam Peninsula in the far north of oman's main territory. In the Gulf of Oman, the width of the road in the strait in the north direction is about 30 miles, and the strait itself runs in the general southwest direction and narrows to about 20 miles wide at the northeast end between Lark Island and Queen Island, which is about 50.8 miles in the north-west direction of the Peninsula. The island of Muzandam, then the width of this peninsula and the east coast of Kichem Island is about 28 miles long and the island of Kichem is about 60 miles long and is located parallel to the Iranian coast and separated from it by the Strait of Clans, a narrow and complex strait (Abbas, 2007).

The economic effects of the closure of the Strait by Iran will be catastrophic for the various economic sectors in the Arab Gulf region and Saudi Arabia, where 90 percent of total oil exports will stop, especially from Iraq, Kuwait and Qatar, which do not have other outlets to export the bulk of its oil production, as well as food prices will jump more than three fold, causing a serious worsening of the current food crisis, and the industrial, shipping, mining and insurance sectors will suffer a major setback. The most important negative economic effects of the closure of the Strait are summarized as follows:

1- The loss of the large revenues from the export of crude oil and natural gas to Kuwait, Iraq, Qatar and partly Saudi Arabia and the United Arab Emirates, which make up the largest proportion of the budgets of these countries, which will expose these countries to a major financial shock

2- Such a closure will have a significant negative impact on food security in the Gulf countries, where food prices will rise more than three times what they are now, especially in countries that are totally dependent on food imports and there is no agriculture, which will lead to a significant rise in inflation rates, which may reach unprecedented levels that will throw additional burdens on citizens in those countries that are not sustainable.

3- The cessation of imports from abroad means that the Gulf countries will lack internationally manufactured equipment, equipment and raw materials, which will harm the market of cars, real estate, manufacturing and other sectors that cannot be secured through land ports with Arab countries or by air transport.

4- The big rise in the prices of insurance and shipping.

5. Investments in the region will be subject to a major shake-up that will have many negative effects on economic life.

6- The extent of the losses will be related to the length of the conflict and the duration of the strait remaining closed, the longer the tension becomes the greater the magnitude of the losses and the worsening of the crises.

In the end, the geographical factors and Iran's economic and military capabilities overlap in the economic threat of the Gulf states, and the geography and its control of the routes of navigation and the Strait of Hormuz in the Gulf region have given great importance to the economic threat to the security of the Gulf in general and the security of Saudi Arabia in particular (Al-Jawayan, 2012).

\section{Military threat:}

The Iranian military threat to the national security of the Gulf and Saudi Arabia is particularly related to Iran's weapons capabilities and its interest in military force since the shah's reign, which relied on the military establishment of "militarization of the state", and this made Iran a significant military force in the Arabian Gulf, the nature of the conflict and the specific tension of the Gulf regional regime in the Middle East pushed Iran to climb as a manifestation of the conflict, and the use of military force to resolve its differences with the Gulf States. In the face of this desire, Iran has sought to increase its capabilities in developing its military power to ensure its control over the Arabian Gulf and achieve its national security, as well as to the military industry, which since the first Gulf War has become an important element of the Iranian war effort (Sabig, 2001).

The first Gulf War and the concerns created by its role in the direction of Iran were the revolution to build a military force based on an internal industrial base, and help other countries, especially Russia, and now one of the most serious threats facing the Gulf states in general, and Saudi Arabia in particular is Iran's weapons 
programs.

In addition to the nuclear programme, which will be adopted as an independent threat, the military threat is based on four military programs:

1- Biological weapons project: which originated in the light of the Iraq-Iran war, where some allegations point to the involvement of the former Soviet Union in helping Iran to test the factors causing certain diseases such as marburg disease, smallpox, plague and talys. "Iran has conducted extensive research on more deadly active factors such as anthrax, foot-and-mouth disease and biological toxins, and some experts believe that Iran is developing the possibility of releasing these biological agents through Scud sand, air-based missiles and other aircraft," another report said. According to the US Central Intelligence Agency, Iran has biological agents that can be fired by artillery and air bombs. It believes iran's Shahab missile is capable of carrying biological warheads. Iran has conducted chemical and biological defense military exercises using spray-propelled helicopters, as well as ballistic missiles and a helicopter, but there is no conclusive evidence that it has developed biological warheads installed on these missiles (Shahata, 2004).

2. The chemical weapons program, which some believe iran has a high-tech base for developing a chemical weapons program dating back to the 1980-1988 Iran-Iraq war, has given Iran a strong incentive to develop a strong chemical defense capability. There are reports of deals for dual-use substances published and known. There are, for example, thyodiglycol and thionyl chloride that can be used for legitimate purposes such as dyes, textiles and pesticides or converted into an illegal chemical weapons programme. Iran also claims that Iran has imported several tons of phosphosphorous pentaoxide, which is used as a medium in agricultural industries, particularlyin the case of pesticides, but can also be a catalyst for unknown nerve gases VX(Shahata, 2004).

3. The missile program, which is of great interest to Iran, which is one of the most effective and diverse missile programs in the world, is under the authority of the Iranian Revolutionary Guard Corps. In particular, the group includes the Shahab-3 liquid-propellant missiles with a range of at least 1,000-1,200 km, as well as Segel-2 missiles with a range of at least 2,000-2,200 km, and in July 2011 Tehran unveiled an underground complex containing missiles placed in silos. These missiles could give Iran a "second strike" deterrence capability and/or pave the way for the installation of heavier missiles with longer range range. In fact, it is an alternative to the Air Force, and this reveals Iran's ambition to have missiles capable of carrying nuclear warheads, for many years working on technology that enables the application of a nuclear warhead to such missiles as evidenced by the tests it conducted in 2004 on the so-called "BabyBottle""design.

Iran's Space Program: now appears to have an actual satellite launch capability and claims to have launched two satellites into space in 2009 and 2011, although at this stage it has the capability to send small and light satellites into space (Terre, 2011).

Hence, Iran occupies the leading position in the Middle East alongside Israel after the end of the Cold War in the programs of land, air and sea armaments production, development and competition in the field of the production of weapons of mass destruction nuclear, chemical and biological, and some centers of strategic studies estimate that the arms expenditures range from 50 to 100 billion in less than ten years,and Iran depends on the development of its weapons on Russia, China and Korea This prompted Saudi Arabia and the Gulf states to engage in an arms race with Iran to counter their threats, and human development statistics indicated that the Gulf states spend eight times what Iran spends on weapons and that this percentage is likely to increase due to iran's successive threats to the Gulf states, its nuclear race and its military exercises in the Gulf. Iran's war spending from 1983 to 2002 amounted to approximately \$137 billion compared to \$533 billion for Saudi Arabia (alCash, 2009).

\section{The objectives and motives of Iran's possession of nuclear weapons:}

Iran confirms that it is developing nuclear energy in order to generate electricity and perfect the fuel cycle to become a supplier of nuclear fuel in the future, and the arguments it makes in support of this claim are of an economic and strategic nature in that together, that Iran is one of the major oil producing countries and will soon be a major producer of gas as well, and it highlights an interest in nuclear technology by referring to the need to diversify its energy sources and maintain its communication with modern technologies like the advanced scientific countries, explains Mohsen Rezai, secretary of the Diagnostic Council. "The important issue is that Iran's energy basket must include a combination of all kinds of energy and that abandoning the nuclear program will harm our national interests," he said. The problem lies in insisting on a full fuel cycle, Guerin will have the capacity to produce the materials needed to manufacture nuclear weapons, and in fact many countries doubt Iran's arguments about its need for self-sufficiency in all aspects of the fuel cycle and its need for energy as a justification for the expansion of the program. (Chopin, previous reference, p.56)

But Iran has not been able to convince other parties in the world, or even in the region, that it needs energy to generate electricity, and the problem is that the Iranian political system does not speak with a single voice in 
the presence of multiple power centers and the Iranian political system includes an ideological current, which was responsible for extremist tendencies towards neighboring countries, and led to the disclosure of secret activities in 2003, and the arrival of Mr. Ahmadinejad to the presidency, exacerbated doubts about intentions and the result that there has always been a problem of trust about the existence of another goal of Iran's nuclear program, this In addition to the political statements accompanying Iran's nuclear activities, it does not indicate in any way that what is being accomplished in Iran is a civilian nuclear program linked to mere electricity and other peaceful purposes, and there are actual practices on the ground in the region consisting of a series of military exercises and the selection of missile weapons, interference in the internal affairs of some Arab countries, in addition to direct action inside Iraq, hence the arab and international concerns about Iran's nuclear capabilities, beyond being a defensive threat, to the political stability of the countries of the region. It indicates that there are several strategic dimensions, clear to the Iranian nuclear project. (Deadmoney, Sherin 2007,p 198)

\section{Iran's motives for acquiring nuclear weapons are:}

Iran's main motive for the pursuit of nuclear weapons is defensive in nature. At a later stage, in parallel with the weakness that Iraq has suffered since the Gulf War, the Iranian regime's attempts to acquire nuclear weapons have become the increasing need it has seen to deter the United States, and to a lesser extent Israel from striking its strategic capabilities against it. (Cam, Ephraim Ex-Reference p. 103-104)

2- Iran is seeking from the nuclear project to extract a regional role - which Iran truly sees it - from the world pole of the United States of America, taking advantage of the absence of the Arab regional project and the confusion of American policy in the sensitivities of the region, it presents a new example in the system of international relations after the collapse of the Soviet Union and the socialist camp, on how to extract the role of regional power without retaining those ambitions of great power, historical experiments have taken place since the end of the Second World War and the emergence of the international bipolar system in our region on the basis that the regional states The admitted in turn already has the basic elements to play that role, but in alliance with one of the two international poles. (Al-Labad, Mustafa 2007 p. 37)

3- Iran's possession of nuclear technology gives additional power to protect the Islamic regime in its region, including the regime's orientations and the revolution calling for the strengthening of national sovereignty and the resignations of the peoples of the region in the face of the Western invasion of Israel. (Mousavi, Sayyid Hussein 2006p6)

4- Nuclear capability will strengthen Iran's position as a mainstay of radical elements inside and outside the region, and it is likely to make moderate regimes in the region more closely align their policies with Iranian policy, and strengthening radical elements could in turn harm the peaceful relations that Israel is striving to build with the Arab world. (Cam, Ephraim Ex-Reference p. 105)

5. The direct threat of Iran's possession of nuclear capability could have an impact on:

U.S. security obligations. This is what President Bush recommended before $9 / 11$, saying that countries violating the Nuclear Non-Proliferation Treaty are "seeking to possess weapons of mass destruction... In order to prevent the United States and other responsible countries from helping allies and friends in the strategic regions of the world, iran will block interventions aimed at aid, create an atmosphere of mistrust and confidence, and act as a obstructive state, especially in Iran's refusal to recognize Israel and its opposition to the peace process in the region.

Iran, the world's most active official sponsor of terrorism, is the most active sponsor of terrorism in the world, and since Iran's policies "directly threaten U.S. interests in the region and beyond, Iran will challenge it on several levels, which will change the military balance in the region, and it can be To pose serious challenges to the United States in terms of deterrence and defense, especially in its ability to reach established bases in the region.

A. The circumstances in which Iran's attempts to acquire nuclear capabilities are taking place are an additional cause for concern: an unstable region, competition, and wars going on. Given the overlapping arab-Iranian, Arab-Arab, Sunni-Shiite and internal national conflicts, as well as short distances between countries, it will be difficult to determine the exact source of any used weapon. (Chopin, Shahram, previous reference, p. 195-197)

The conclusion.

For more than 50 years, the United States has been practicing on the territory of our Arab world 'as part of the world, the Strategy of the Chinese Table is driven by events, and it is hidden behind a curtain, so that it shows that the events were self-moving, and the result is that it imposes on the countries of the region the form of a priority, without direct intervention, draining its effort and energy in regional and civil wars, arms race, conflicts, clashes and above all freezing the process of political reform and the freedom of the peoples. But it is certain that this is a stage of an era that has an idea, philosophy, strategies, circumstances, scope, and political instruments, and because this Arab region has a rare historical opportunity to pull its threads to the fingers of its hand, it holds it, and does not leave it to others to move it and control it by putting Its mandates, and the change of the old course, because many profound changes in the world in the periods of the past ten years, would weaken the 
Chinese table machine and possibly stop its work and disrupt it, and the analogy here is that the strategy of the United States in a number of regions of the third world, especially the East In the years of the Cold War, it was playing its role similarly, regional events are taking place, and their heroes are moving, and they are parties to these events, but their movement is taking place on a ground made by American policy and planned, controlling its movement like a turntable on the Chinese table, controlling the moment it is stopped, and those who move over it remain convinced that they are the makers of these events and are their heroes, while the truth is quite the opposite, a method that was being practiced in the context of the conflict that was going on between the West in the years of the Cold War, and as part of the East, as part of the East, and the East. The theory of "containment", which formed the political philosophy of the United States and the West, complements the practices of the back doors of foreign policy, i.e. assassinations, coups and the igniting of conflicts between states or within states between their sects and religious and political currents.

With September 11, 2001, the United States faced a real challenge to redraw the U.S. strategy on the basis of the development of selective intervention, especially since 40 countries had shown their attack on Afghanistan compared to 28 countries in the case of military action against Iraq in 1991. On September 20, 2002, The White House said it was considered a new U.S. strategy, and the report was found to be a turning point between two policies: the policy of containment and deterrence and the second: the policy of eliminating enemies, but the report did not make the strategy of direct intervention absolute, if it recognizes the need to deter first and then move to eliminate the enemy if deterrence fails. But the smell of gunpowder and blood thinners is evident in that strategy when we acknowledge that "the United States has a status unprecedented in history, militarily, economically and politically, and now it finds itself faced with a moral duty and historical responsibility." George W. Bush in the new strategy when he said, "There is a difference between running the world and controlling it" and here we note the new strategy prefers to control the administration.

After the victory in Iraq, US Secretary of State Colin Powell spoke of a new strategic environment in the Middle East as one of the important things that this victory contains... The main step to change the middle east has already begun with the process of liberating Iraq and may be considered realistic, as Powell described it as "a new strategic environment or, for the better part of the world, a regional salvia that has profoundly altered the political landscape in the region." As a result of the successful liberation of Iraq, America could be attracted to changes in the Middle East and should be as follows:

A- Regimes opposed to Us interests should be given the opportunity to reform their position or remove them altogether.

B- It should seek to spread democracy in the Middle East, as this can be implemented without prejudice to the current regimes.

A. The United States should seek to bring about changes in governance, regional changes, and promote liberal democracy.

Terrorism is a serious and important threat and is inexorably linked to problems with Iran and Syria.

But the bloody events that took place in the Arab region as a result of the American invasion of Iraq and Afghanistan, which led to the spread of chaos and unrest, and resulted in the spread of terrorism, contributed to the explosion of crises and imbalances and the growth of fundamentalism, and caused increased feelings of hatred and hostility to American politics In the Arab and Islamic streets, she explained to the Americans the limitations of the American military force despite its greatand moderate, political shortcomings to change systems and modify the culture of societies using means of force and methods of pressure, and the difficulty of reaching the "minds and hearts" of the people swayed by media movements and not by political decisions, The U.S. government has pushed for some change in the guidelines for its trends in the region in the following directions:

First: To undo the idea of changing the ruling regimes in the Arab region, in order to be a strong alternative with anti-American orientations, and national military systems with few experience, and with reckless and violent reactions to win the political street, especially in light of the enjoying of the Americans good relations with the Arab regimes, and a long experience in knowing their paths and means of access and methods This does not necessarily reflect an American tendency to avoid pressure on Arab regimes when necessary, or to reverse its policy of redrawing the political and geographical map in the region and changing the balances of power within it.

Secondly, stop trying to impose democracy in the Western "integrated" concept of the countries of the region, and start preparing to understand the specific internal conditions of these countries, and accept the idea of gradually making the required changes, and the method of practicing the democratic process on steps, while pushing these countries to maintain the democratic "form" of regimes and not to overuse the instruments of repressive power in order to avoid embarrassing the American administration in light of its declared commitments to the dissemination of democracy.

The united nations has been working to find a way to achieve the goals of the United Nations.

It can be said that the U.S. policy toward the Arab region during the presidency of Bush Jr. began on three main 
pillars:

First, work to redraw the political features and characteristics of the countries of the region in order to become more democratic and open.

Secondly, to prevent the emergence of any political currents or forces that are intellectually and ideologically anti-Us, and to pressure them to get rid of them, if any, under the pretext of war on terror.

"It is a second step in u.S. foreign policy toward the region, but it has gained new dimensions, launched by the arrival of the Bush administration in the White House, and the transition of the relationship between Washington and Tel Aviv to take the form of "political twins" as an alternative to the strategic alliance.

The governing framework of these three pillars follows that the United States no longer views the Arab world as a strategic partner as much as it is an extension of American national security, and the difference between the two situations is significant, of course, considering the Arabs as a strategic partner, providing opportunities for the meeting of the two parties at common interests and visions, and may reduce the Arab fear of the deviations of The United States foreign policy toward the region, while considering the region as an extension of the security of the United States makes the relationship between the two parties a relationship dependent in favor of the American side of course, which may constantly pre-establish the state of tension On both sides, this does not diminish the attempts of the emerging amateur bridge between the Arabs and the United States.

When Obama came to Cairo to deliver his address to the Islamic world on June 4, 2009, because he fully believes that his country's policy toward the Islamic world has proved to be a failure, and that it is time to try a new policy based on a different vision, in other words, he came to Cairo for the sole purpose of the interest of the United States of America and nothing else, and that Obama's speech carried a number of important shifts in political orientations, and even criticisms of the Foreign Policy of the United States under Bush from Iraq, through civil liberties, and through civil liberties, and through If so, the speech at Cairo University and not the U.S. Congress becomes much stronger and not the other way around, perhaps the first time that an American president has stood outside the territory of the United States of America and criticizes the foreign policy of his predecessor, and that is a matter that is not familiar, but reprehensible within the United States, and also other cultures, and hence what Obama did courage derived from his popularity, which was high at the time of the speech, and from the desire to reflect the polls of my opinion. the American world in changing the policies pursued by Bush.

Perhaps the worst outcome of the Bush administration's war on Iraq is that the Arab region has become a completely different regional landscape from what Bush inherited on the eve of his accession to power in 2000 . 03, the War of Lebanon 2006, and the Gaza War 2008, and the legacy of these wars of roles and weights in the region so that it gave preference, not only to regional powers that have always been looking for a foothold in the Arab courtyard, but also It is also a Middle East in which the chances and options for peace with Israel are declining and there is an increasing preference for resistance, conflicts and civil conflicts. On this logical result of all these situations, it is possible to monitor the main features of this new regional system, the most important of which are:

First: The transfer of the centers of gravity in the interactions of the regional system from the heart (Egypt, Saudi Arabia, Iraq) to the parties (Iran and Turkey) in addition to the end of the myth of arab balance with Israel, the main interactions in the region are mainly non-Arab interactions, and they are distributed as follows: U.S.Iran interactions, Iranian-Israeli interactions, Israeli-Israeli interactions, Israeli-Israeli interactions, and all arab parties in the roles of catalyst (Syria) or the facilitator "Qatar, Hezbollah and Hamas", and the United States sees no threat to its interests in the region more than the emergence of the power of Iran. Washington's insistence on appeasing Tehran seems to be an explicit recognition of the extent of its influence, and an implicit consolidation of its role as an authentic party in the management of Arab-Arab interactions, while Israel seems terrified of the Iranian threat that is now encircled by its arms. Turkey is playing to the tune of tension in the region, and is employing it to serve its reconciliation, whether by acting as a "mediator" for regional and Arab differences (e.g. mediation between Damascus and Tel Aviv, or between Hamas and Fatah, and possibly between Tehran and Damascus). In the future, or by bidding on Western issues by alerting the Ottoman spirit against Tel Aviv, as its prime minister has always said.

Secondly, there are strategic shifts in the regional security system, which reflect in practice the end of the "Arab regional security" thesis, replaced by the thesis of bilateral security arrangements. Security between Tel Aviv and Washington, which undermines Arab security from the door of mandab to the Mediterranean, and through the formula of a security alliance between Israel and major European powers such as France and Germany in order to stop the smuggling of weapons to Hamas.

These developments in the region have resulted in the crystallization of conflicting trends in Arab politics characterized by the clash of concepts, the struggle of the wills, the competition of the axes, the difference of opinions about putting the activity of resistance in a position contrary to the responsibilities of the state, and the difference of appreciation regarding the consideration of Iranian activity as the main source of threats to the Arab 
countries, and the decline of the Israeli role in the Arab perception to a late arrangement, which increased the manifestations of division and fragmentation in the Arab side, and increased the atmosphere of tension and attraction in regional relations, at the same time as the policy moves The new U.S. administration in a different direction is to focus on the line of openness and calm in the region, starting from the escalation of its relationship with Turkey to be an "outlet" on its on the Islamic world, and dealing with it as a model state on its own, and through the aspiration to start a comprehensive dialogue with Iran covering all regional issues, and ending with attempts to move efforts to achieve a peaceful settlement in the Palestinian issue on the basis of a two-state solution, and a clear contradiction with the policy of the new Israeli government.

The current U.S. transformations not only reshape Arab-American relations, but also their regional counterparts, from a completely different perspective from what the administration of former President George W. Bush did through the shifts in U.S. policy to the new administration in the following:

First, the Obama administration has moved from the policy of escalation and confrontation with Iran to attempts to contain by opening a direct dialogue with Tehran, and with many signals, all of which consolidate a major break with the policies of previous U.S. administrations that lasted for nearly three decades, and this new U.S. trend has confused the calculations of the Arab parties, which have often bet on the continuation of U.S.Iranian tension, and what may provide them with regional conviction that may prevent the increase of Iranian influence, while some have built their calculations on the ability of the United States to "We have been quick to send messages to the Arab parties that their security and stability will not be sacrificed in any deal with Tehran," he said.

Secondly, the United States seems to benefit from the reformulation of alliance relations in the region, whether between old adversaries such as Syria and Iraq, or between new competitors such as Turkey and Iran, which puts enormous pressure on old allies such as Egypt, Saudi Arabia and Jordan, and forces them to reevaluate their regional relations by moving away from polarization and congestion to realism and strategic partnership.

"The continuation of the State of Iran and its unlimited pursuit of nuclear technology, whether it is for the peaceful purpose as described, or in the military as it is convinced at the global level, prompts the countries of the region to follow in the footsteps of the Iranians, and at the same time we find that an unstable region such as the Arab region and the fear of the danger expected from Iran may be the motive and the real reason why other countries in the region seek to acquire nuclear technology," he said.

Although Iran is seeking to sow conviction in the Middle East that its quest to benefit from nuclear technology, it will reflect on the Muslim world without distinction between Sunnis and Shiites, but this narrative is considered unacceptable and unconvincing to the countries of the region, especially Saudi Arabia, and it continues to make military deals and seek stake in the pursuit of nuclear technology, as it continues to sense the danger and the Iranian threat seriously, and realizes the goals and ambitions of Iran. Despite the need for nuclear energy, despite the need for nuclear energy, these countries assume that this will act as a real deterrent against the threat expected from Iran, bearing in mind that these dramatic developments in the region and the various reactions between the countries of the region, led by Saudi Arabia and

Iran, are the focus of attention and anticipation of all the countries of the international community, led by the United States of America.

\section{References}

A. Arabic references:

Abu Dawood, Abdul Razzaq bin Suleiman bin Ahmed, (1491H), King AbdulAziz and the Geopolitical Construction of Saudi Arabia, King Abdul-Aziz University Magazine, Saudi Arabia.

Abu Amud, Mohammad Saad, (2000), Reality of Saudi-Iranian Relations, International Politics Magazine, Issue 144.

Ahmed, Ahmed Youssef(1990), Egypt's Foreign Policy in a Changing World,Cairo, Center for Research and Political Studies at the Faculty of Economics and Political Science, Cairo University, Cairo.

Driss, Mohammed Al Sayed, (2000), Regional Order of the Arabian Gulf, Center for Arab Unity Studies, Beirut.

Al Saud, Abdul Aziz, (1996), the most important external challenges and threats facing Saudi national security and the most appropriate strategy to confront them, an unpublished master's letter, Nasser Academy, Riyadh.

Al Saud, Faisal, (2002), the political development of Saudi Arabia and the evaluation of the Shura Council, I1, (D.M.).

Amir, Noha Ali, (2005), Shi'a Crescent and the Limits of Influence on the Security of the Arabian Gulf, Gulf Affairs Magazine, Issue 41, p. 89

Isidi, Bezen, (2000), an introduction to the foreign policy of the Islamic Republic of Iran, translated by Saeed Al-Sabbagh, First Edition, Cultural Publishing House, Cairo. 
Badib, Saeed, (1994), Saudi-Iranian Relations 1923-1983, Dar Al-Saki, Beirut.

Bakir, Ali (2008), towards strategic Turkish-Gulfrelations, Gulf Research Center, Opinions on the Gulf. Available viaalibakeer. maktoobblog.com/

Al-Beheiry, Ahmed, (2010), Map of Political Parties and Forces in Iran, Iranian Anthology Magazine, without number, available via link: http://digital.ahram.org.eg/articles.aspx?Serial=325546\&eid=2995

Badawi, Munir Mahmoud, (1997), The Concept of Conflict: A Study of The Theoretical Origins of Causes and Types, Journal of Future Studies, ThirdIssue, Center forFuture Studies, July 1997.

Bradley, Atair (2004) "American Peace in theMiddle East" America's Major Strategic Interests in the Region After September 11" translated by Imad Fawzi Shuaibi, I1, Arab House of Science Publishers, Beirut-Lebanon.

Al-Tabyiji, Ayad Ahmed, (2011), Reading in Iranian Foreign Policy: The Force Selector, 2011, available at http://minbaralhurriyya.org/index.php/archives/4488

Al-Balauna, Ali (2004)"U.S. Pressure on Iran - Nuclear Or Vital Facilities" Strategic Affairs Magazine, Year 2, Issue 10, 2004.

Borno Terte, (2011), Iran's missile program lies nuclear ambitions, a published translated study available at link: http://www.realite-eu.org/site/ apps/nlnet/content3.aspx?c=9dJBLLNkGiF\&b=5067613\&ct=10893861

Bebars, Samia (2010), Turkey's Growing Role in the Middle East, Arab Affairs Magazine,Issue 141, p. 171.

Al-Beyna, (2011), analysts: Saudi Arabia faces The Iranian threat to diversify arms sources,available via link: http://www.islammemo.cc/ akhbar/arab/2011/07/10/129191.html

Bayoumi, Zakaria Suleiman (2009) "The Arabs between Iranian influence and the American-Zionist scheme" I1, Dar al-Alam and Faith For Publishing and Distribution - Dsouk.

Bayoumi, Zakaria Suleiman (2009) "The Arabs between Iranian influence and the American-Zionist scheme" I1, Dar al-Alam and Faith For Publishing and Distribution - Dsouk.

Chopin, Shahram, (2007), Iran's Nuclear Ambitions, I1, translated by Bassam Sheeha, Arab House of Science Publishers, Beirut, Lebanon.

Annual Statistical Report - Ministry of Planning of Iran - 2003

Tawfiq, Saad Haqqi, (2003), Arab International Relations at the beginning of the 21st century, first edition, Wael Publishing House, Amman, Jordan.

Tawfiq, Saeed Haqqi (2000) "Principles of International Relations" i1, Dar Al-Awliya Printing and Publishing.

Terry Tocqueville, (2008), Iran: The Hidden Revolution, translated by Khalil Ahmed, Dar Al-Farabi, Beirut.

Jad, Emad (2003)"The repercussions of the US invasion of Iraq ... On Israel's role in the region,Arab affairs, issue 113, spring 2003.

Jad, Emad (2009)"Israeli efforts to neutralize the dispute with U.S. policies" Arab affairs, Issue 139 - Autumn 2009

Jawareen, Adnan Farhan, (2012), the economic effects of the closure of the Strait of Hormuz on the Gulf economies and on the Iraqi economy in particular, a study published via the link: http://www.ahewar.org/debat/show.art.asp? Aid = 293846

James, Rachel (2008) "Regional Threats and Security Strategy: The Current Worrying Situation inthe MiddleEast" by على الرابط :the Center for Strategic Studies of the American War College atwww.ALZYTOUNA. NET

Even, Nassif, (1985), Theory of International Relations, Arab Book House,Beirut.

Alhurob, Khaled (2006)"Iran challenges (or change) regional power balances"Arab Affairs Issue 125, spring 2006.

Hariri, Jassim, (2008), Saudi Foreign Policy: Changes and the Future, Middle East Affairs, Issue $129 .$.

Al-Helwani, Saad, Al-Ghamdi, Mohammed (2000), Modern and Contemporary Saudi History until the end of the 20th century, New Valley of Printing, Cairo, Egypt.

Hanna, Elias (2009) "The Arab region in the post-Gaza war" Arab Affairs, Issue 137, Spring 2009

Haidar, Mahmoud (2011) "Theological Foundations of U.S.-Israeli Relations"Middle East Affairs, Issue 137, Fall 2010-Winter 2011.

Al-Khazraji, Thamer Kamel (2005) "International Policy Relations - Crisis Management Strategy" i1, Magdalaoui Publishing and Distribution House.

Al-Khatib, Alaa, (2011), History of the Iran-Saudi Conflict,Episode II, available on the website:

Dajman, Ali, (2007), Iran's regional priorities in the 20th document, study published via link: http://www.albainah.net/index.aspx?function=Item\&id=17106\&lang =

Drom, Jessica, (2008), Saudi Arabia's reaction to Iran's development of the nuclear program, available via link: http:/www.albainah.net/index.aspx?function=Item\&id=8645\&lang =.

Darwish, Madiha, (1980), History of the Saudi State until the first quarter of the 20th century,I1, Dar Al Shorouk, Jeddah, Saudi Arabia. 
Al-Rajhi, Saleh Abdullah, (1419 H), Saudi-Gulf Relations, in the book: Foreign Policy of Saudi Arabia, Publications institute for diplomatic studies, Riyadh.

Al-Rashidi, Fayez Salman, (2007), Iran-UAE Relations,available at: http://acpss.ahram.org

Rampstone, Sheldon and Stober, John, (2003). Weapons of mass deception,I1, Arab House of Science.

Ray, Milan, (2003). The war on Iraq: The regime has not changed, the plan to invade Iraq, translation: Hassan al-Hassan, I1, Arab Book House: Beirut.

Al-Rubadi, Mohammed, (2005), Studies in the Population of Saudi Arabia - Population Information and Data Sources,I1, Marina Company, Riyadh, Saudi Arabia.

Raslan, Amal (2011) "A New Saudi-Iranian War in Bahrain" is available via link: http://www.youm7.com/News.asp?NewsID=393581

Al-Rashwani, Manar Mohammed(2004). Occupation of Iraq: Goals - Future Results,I1, Center for Arab Unity Studies: Beirut.

Rifaat, Said (2006) "U.S. Trends and New European Transformations in the Region"Arab Affairs, Issue 125, Spring 2006.

Russia Today, (2011), Iran's nuclear program is a destabilizing factor in the Near and Middle East,available via link: http://arabic.rt.com/forum/showthread.php/80161

Al-Ruweithi, Mohammed, (1996), Geographical Figure of Saudi Arabia - Study in Regional Geography, I1, Library of Repentance, Medina, Saudi Arabia.

Al-Ruwaili, Ali (2010), Saudi National Security - Strategic Prospects with A Future Vision, I1, Besan Publishing, Distribution and Media, Beirut, Lebanon.

Zayed, Hani, Issa, Ayman, (2011), Iranian interference in Arab affairs... Change of heads and stability in goals,available via the link http://www.alwatan.com.sa/Politics/News_Detail.aspx?ArticleID=48236

Zarkli, Khaireddine, (1985), Peninsula during the reign of King Abdul Aziz,Daral-Alam for Millions, Third Edition, Beirut, Lebanon.

Al-Zoubi, Mohammed (2007)"The New American Colonization of the Middle East - Its Features and Implications"I1, Department of the National Library - Jordan.

Zahra, Mr., (2007), The Ambitions of Iranian Hegemony http://www.al-moharer.net/.

Al-Zuhairi, Abu Bakr Murshid (2008), Iranian trends in the Arab region and its impact on national security,I1, Sadiq Library, Sana'a, Yemen.

Aatati, Amin, (2011), Bahrain Strategic Depth of Saudi National Security, Electronic Economic,No. 6376.

Salem, Paul and others (2008), New Middle East, Carnegie Foundation for International Peace,Beirut, Lebanon ، بول و اخرون

Al-Saadoun, Jassim Khaled, (1995), Arab-Iranian Economic Relations and Prospects for Development - Arab Paper - Arab Future, Issue 202..

Said, Abdel Moneim, (1987), Arabs and geographical neighbors, Center for Arab Unity Studies, Lebanon, Beirut..

Al-Saeed Idris, Mohammad (2009) "The Crisis of Iranian Politics and Its Foreign Implications" International Politics, Issue 178, October 2009

Al-Saeed, Driss Mohammed, (2006), Gulf and The Iranian Nuclear Crisis, International Politics Magazine,Issue 165.

Scott, Kendall (2009) "The Dynamics of U.S. Foreign Policy Making",International Politics, No. 178, October 2009.

Al-Suwaidi, Jamal, (1996), Iran and the Gulf - Seeking Stability,I1, Emirates Center for Strategic Studies and Research, Abu Dhabi, United Arab Emirates.

Sweelm, Hussam, (2001), Strait of Hormuz at the epicenter of the Iran-U.S. conflict, Iranian Anthology Magazine:A study of advice available via link: http://acpss.ahram.org.eg/ahram/2001/1/1/CIRN50.HTM

Mr. Morteza, (2012), has the state become just a summer cloud: the role of the tribe and its future in Saudi Arabia, available via link http://www.gulfissues.net/m_p_folder/main_div/sociology/sociology_001.htm

Simmons, Jeff, (2003). Targeting Iraq: Sanctions and Raids in Politics The U.S.. I1, Center for Arab Unity Studies: Beirut.

Shehata, Amin, (2007), Iran's Weapons Program, Al Jazeera Center for Studies - Knowledge:Special Files Available via link: http://www.aljazeera.net/specialfiles/pages/d33e086c-39c4-42dc-977a-7272bb279f68

Shehata, Nasser, (2007), Saudi-Iranian Dialogue: Regional Implications,Political Issues, Emirates Center for Strategic Studies and Research, Abu Dhabi.

Al-Sharif, Abdul Rahman Sadiq, (2007), Geography of Saudi Arabia,Part 1, Dar al-Mars, Riyadh, Saudi Arabia.

Shakala, Ahmed (2003), Iran, Iraq and Turkey: Strategic Impact inthe Arabian Gulf, (I1), Emirates Center for Strategic Studies and Research, Abu Dhabi-UAE. 
Sadiq, Ali, (2006), what do you know about Hezbollah, political issues,i1, copyright reserved for the author.

Strict, Samir, (2003), Arab Oil in American Strategy, Political Thought Magazine,Year 6, 18th and 19th Editions, Spring/Summer 2003.

Saleh, Mohsen (2011) "Zionist Lobby in America", Middle East Affairs, Issue 137, Fall 2010-Winter 2011.

Al-Samadi, Fayez Abdul Majid, Bani Melhem, Ghazi Saleh, (2009), Iran's nuclear program and The Security of the Arabian Gulf: (Analytical Study), Al-Manara Magazine,Volume 15, Issue 3.

Al-Samadi, Fayez Abdul Majid, Bani Melhem, Ghazi Saleh, (2009), Iran's nuclear program and The Security of the Arabian Gulf: (analytical study), Al-Manara magazine,Volume 15, Issue 3.

Student, Mohammed Saeed, (2006). The Us occupation of Iraq facts, results and prospects,editor,issue 173. Available at:http://www.al- moharer.net/moh/73/malaf/73-90.htm.

Taher, Ahmed, (2009), Yemen and the Houthis - The Limits and Implications of the External Role, International Politics,No. 178, October 2009, p. 160-161.

Taqoush, Mohammed, (2009), History of the Safavid State in Iran,I1, Dar al-Nafis Printing, Publishing and Distribution, Beirut, Lebanon

Abdel Salam, Ahmed Lotfi (2005) "American bias towards Israel with its historical, social and political motives"i1, window library.

Abdel Fattah, Bashir, (2010), Iran and Arab Shiites---- thorny relations, Arab affairs,No. 144, winter 2010..

Abdul Moez, Sally (2009), Houthis in Yemen — Fears of a New War, Affairs,No. 177, July 2009..

Abdullah, Mohammad, (1999), Iranian Foreign Policy: Analysis of Decision Industry, International Policy Journal, Issue (138).).

Abboud, Assaad, (2011), arms deals reflect saudi arabia's declared package stake in Iran,Middle EastOnline, available via::http://www.middle-east-online.com/?id=113879

Obeid, Samir, (2010), The Nature of the Iranian Personality and Its Relationship with Theocratic Isma'ia, a published study available online: http://www.ahwazna.org/details.php?recordID=20

Al-Obaid, Abdullah, Attia, Abdul Qadir Mohammed Abdul Qadir, (1994), Saudi Arabia's Economy Analytical View, World of Books For Printing, Publishing and Distribution, Riyadh, Saudi Arabia.

Al-Atrisi, Talal, (2006), The Difficult Republic: Iran in Its Internal Transformations and Regional Policies, Dar Al-Saki, Beirut, Lebanon.

Arabic. Net, (2011), Bahrain's Foreign Minister warns of Iranian danger and calls on Arab countries to address it,available via link http://www.alarabiya.net/articles/2011/11/02/175065.html

Azbawi, Yusry Ahmed (2008), Turkish-Arab Relations Opportunities for Turkish-Gulf Rapprochement, Journal of Cooperation,No. 66, 228-239.

Allam, Mustafa Shafiq (2010), Turkish-Gulf rapprochement. Motives, Motivations and Effects, International Politics Journal,October, Issue 182, p. 130-131.

Al-Ali, Khalid bin Abdul Rahman, (1419H), Foreign Policy and Its Movement Circles, in The Foreign Policy of Saudi Arabia, Publications of the Institute of Diplomatic Studies, Riyadh..

Ali, Mahmoud Abdo, (2008), Saudi Arabia and Iran, initially the conflict was,Aram newspaper, 19/11/2008.

Annan, Coffey, (2003), Press Release,March 19, 2003/ March 2003 SG/SM/8643 SC/7698,

Anani, Khalil (2009) "New Power Centers in the Middle East"Arab Affairs, No. 138.

Anani, Khalil, (2009), New Centers of Power in the Middle East, Arab Affairs,No. 138..

Eidarossi, Mohammad Hassan, (1985), Arab-Iranian Relations 1921-1971, Chained Publications, Kuwait.

Al-Issawi, Ashraf Assaad, (2006), the repercussions of sectarianism on security and stability in the region, foreign affairs magazine, Tala47.

Stranger, Natalia (2010)." The Gas Emperor, translated by Ammar Qat, Publishing House, Madboli Library, Cairo.

Farouk, Walid, (2005). The children of Iraq are asking for any guilt to kill, Islam Online.net. . Available vialink: WWW.islamonline.net

Al-Faleh, Left, (2002), Reform in the Face of Collapse or Division, is available via the link http://www.achr.nu/art8.htm

Valenstein, Peter, (2005), an introduction to understanding the settlement of conflicts: war, peace and world order,il, Scientific Center for Political Studies, Amman, Jordan..

Poor, Badr, (1998), Elements of Power in The Unification of Saudi Arabia - Analytical Study in Geopolitics, I1, (D.M.).

Fahmy, Abdelkader Mohamed, (2011), Partial and Holistic Theories in International Relations,Dar Al Shorouk, Cairo, Egypt.

Al-Qubaa, Abdullah, (1990), International Strategy and National Security Issues in Saudi Arabia, I2, Riyadh, Saudi Arabia.

Jerusalem, (2011), The Fall of Saudi Strategic Security Theory, Al-Hijaz Electronic Magazine,available via link: http://www.alhejazi.net/seyasah/index.htm 
Qatishat, Yasser, (2011), Bahrain's crisis and its repercussions between Gulf concerns and Iran's ambitions, urban dialogue,no. 3307, available on the website::

Kash: Ali, Turban of Mullahs and The Energy of The Jews: Strategy unit and tactical differences (Zionist and Iranian arms race), Basra Network, Saturday, February 22, 1430 / 18 April 2009 net/ar articles 2009/0409/kash 180409.htm http://www.albasrah.

Kazem, Mohammed (2007), "The New Russian Sparkle", Drup Magazine,Qatar, Issue 924,

Kosach, Griffith, (2005), The Development of Saudi Foreign Policy: The Art of The Establishment of the State to the Beginning of Reforms, Institute of Diplomatic Studies, Saudi Foreign Ministry..

Majid, Ali (2011)"Russia and its big neighbors in the struggle for influence in Asian republics", , March 26, 2011, Iraqi News Agency Website Iraq for All, Publisher Dar al-Hayat)

Al-Ma, Saleh, (1996), The Ideological Dimension in Saudi-Iranian Relations, in Iran and the Gulf: The Search for Stability, Emirates Center for Strategic Studies and Research, UAE.

Bleachin, Mukhald, (2008), Gulf-Iran Relations 1997-2006 (Saudi CaseStudy), Al-Manara Magazine,Volume 14 , Issue 2.

Majali, Essam, (2007), the impact of armaments on Gulf security since the 1979 Islamic Revolution, an unpublished master's thesis, a university library.

Majali, Essam (2007) "The impact of armaments on gulf security newspapers and magazines since the Islamic Revolution of 1979" an unpublished master's letter, The Library of The University of Mutata

Mahmoud, Khaled, (2005), Foreign Policy Decision-Makingof the Islamic Republic of Iran, Dunya Al Watan, available via link: http://pulpit.alwatanvoice.com/articles/2005/06/13/23634.html

Makhlouf, Dia (2010), "Russia and the), Attempts to Resurrect Soviet Anchors and Horizons": Available via http://democraticac.com.

Al-Mas'ad, Nevin Abd, (2000) Iran. Where to, Arab Future Magazine, Issue 365.

Massad, Nevin Abdel Moneim, (2002), decision-making in Iran in Arab-Iranian relations,i1, Center for The Study of Arab Unity, Hamra, Beirut, Lebanon.

Maqlid, Ismail Sabri (1982)"Theories of International Politics" i1.

Maqlid, Ismail Sabri, (1982), Theories of International Politics,I1, (D.M.).

Al-Mallah, Jamal,(2011), Shia Saudi Arabia, Do You Ignite a Civil War, Arab Media Network, available athttp://www.lahona.com/newsS ave.aspx?nid=454257

Mahaba, Ahmed, (1991), Iran and Gulf Security, International Politics Magazine,Issue $105 .$.

Mirschmer, John (2006) "Views on Israeli Influence in the U.S. Foreign Policy Industry,"Foreign Policy, Zaytouna Translation Series (June 18, 2006).

Nafia, Hassan (2005). The situation in the region after a year of american invasion and occupation For Iraq, Short for News, available via http://www.almokhtsar.com link http://www.almokhtsar.com

Nafia, Hassan, (2003), Perspective: The Evolution of the U.S. Vision toward the Arab World, International Politics Magazine,Issue 166, October 2006.

News, (2009), Iran escalates its war on Saudi Arabia and its gatherings with theHouthis, available via link: http://www.nabanews.net/2009/22342.html

Al-Nabali, Abdullah, (2003), political life in the Islamic Republic of Iran,I1, Amman,Jordan.

Noureddine, Muhammad (2006), Turkey's regional policy between internal sensitivities and external considerations, Arab Affairs Magazine,Issue 126.

Halper, Stefan and Clark, Jonathan, (2005). American Exclusivity: Neo-Conservatives and the World Order Translation: Omar Al-Ayoubi, Arab Book House: Beirut.

Al-Hadal, Mohammed, (2011), Saudi National Security Council - Security and Military Strategic Tasks At The Domestic and External Levels,Al Jazeera, No. 14107.

Heikal, Mohamed Hassanein (2003). The American Empire and the Raid on Iraq, Egyptian Arab and International Publishing Company: Cairo.

Wahid, Tigris, (2006), The Occupation of Iraq, the Korean Nuclear Test and the Role of the Iraqi Resistance in the Korean-Chinese Political Victory, Liberated,Issue 249, available via link:www.almoharer.net

English references:

Schells, Jonathan (2004). The Vietnam War on Trial : The MyLai Massacre and the Court-Martial of Lt. Calley ion.

Carison, Darren K (2003). Action or Isolation: Americans Ponder U.S. Role.Gallup Poll Social Series World Affairs.

Dunne, Michael (2003). The United States, the United Nations and Iraq International affairs, 79(2), $257-277$. 